\title{
Mantle metasomatism influence on water contents in continental lithosphere: new constraints from garnet pyroxenite xenoliths (France \& Cameroon volcanic provinces)
}

\author{
SAMANTHA AZEVEDO-VANNSON ${ }^{1}$, LYDÉRIC \\ FRANCE $^{2}$, JANNICK INGRIN ${ }^{3}$ AND GILLES CHAZOT ${ }^{4}$ \\ ${ }^{1}$ IMPMC \\ ${ }^{2}$ Université de Lorraine, CNRS, CRPG \\ ${ }^{3}$ Univ. Lille, CNRS, INRAE, ENSCL, UMR 8207 - UMET - \\ Unité Matériaux et Transformations \\ ${ }^{4}$ Université de Brest \\ Presenting Author: samantha.azevedo-vannson@mnhn.fr
}

Quantifying water contents of the lithospheric mantle is key for our understanding of global geodynamics, mantle composition and related physical properties. Most of the mantle lithologies contain little water, but some heterogeneities like pyroxenites, likely contain more water, and by their mineralogical assemblage melt at lower temperatures. The quantification of their water content brings new information about water distribution in the mantle. This study focuses on two continental lithospheric domains: the Massif Central (France) and the Adamawa Volcanic Plateau (Cameroon). Garnet pyroxenites in Adamawa Volcanic Plateau are more hydrated $\left(\left[\mathrm{H}_{2} \mathrm{O}\right] \mathrm{Cpx}=386-685\right.$ ppm; $\left[\mathrm{H}_{2} \mathrm{O}\right] \mathrm{Opx}=124-155 \mathrm{ppm}$; $\left[\mathrm{H}_{2} \mathrm{O}\right]$ Garnet $\left.<0.5 \mathrm{ppm}\right)$ than those of French Massif Central $\left(\left[\mathrm{H}_{2} \mathrm{O}\right] \mathrm{Cpx}=112-465\right.$ ppm; $\left[\mathrm{H}_{2} \mathrm{O}\right] \mathrm{Opx}=61-104$ ppm; $[\mathrm{H} 2 \mathrm{O}]$ Garnet $<0.5 \mathrm{ppm})$. These water concentrations are representative of lithospheric water (no water loss during xenolith ascent), however water content of French Massif Central pyroxenites have been modified by metasomatism. Pyroxenites have been dehydrated by a hot carbonatitic fluid, whereas rocks of Adamawa Volcanic Plateau were likely not affected by metasomatic events. In both regions, the metasomatic episodes modified the LREE contents (e.g., Ce). Consequently $\mathrm{H}_{2} \mathrm{O} / \mathrm{Ce}$ ratio, which could be a good source tracer, might not be the most appropriate tool to identify pyroxenites implication in magmas genesis. 